\title{
Comparative ligninolytic potential of Phlebia species and their role in improvement of in vitro digestibility of wheat straw
}

\author{
D.S. Arora ${ }^{1}$ and R.K. Sharma \\ Microbial Technology Laboratory, Department of Microbiology, \\ Guru Nanak Dev University \\ Amritsar - 143005, India
}

(Received 9 June 2008; revised version 24 December 2008; accepted 23 January 2009)

\begin{abstract}
Digestibility of crop-residues can be enhanced by the delignification, which improves its nutritive quality. Presence of lignin in these crop-residues which act as digestibility barrier can be degraded by fungi. The biodelignification ability of three Phlebia species: Phlebia radiata, Phlebia fascicularia and Phlebia brevispora, was studied under solid state fermentation of wheat straw for 30 days and compared with that of much studied white rot fungus Ceriporiopsis subvermispora. Different parameters including laccase activity, loss in total organic matter, water soluble content, hemicellulose, cellulose, lignin, ash content, change in $\mathrm{pH}$ and effect of the chitin content of fungus on in vitro digestibility were examined before and after the fungal treatment of substrate. P. brevispora caused maximum lignin loss of $305 \mathrm{~g} / \mathrm{kg}$ with the lowest loss in total organic matter $(105 \mathrm{~g} / \mathrm{kg})$ and enhanced the digestibility to its maximum extent $(259 \mathrm{~g} / \mathrm{kg})$. C. subvermispora which degraded $230 \mathrm{~g} / \mathrm{kg}$ lignin gave maximum in vitro digestibility of $221 \mathrm{~g} / \mathrm{kg}$ only.
\end{abstract}

KEY WORDS: in vitro digestibility, chitin, ligninolytic activity, solid-state fermentation, white rot fungi, wheat straw

\section{INTRODUCTION}

Several crop-residues like wheat straw, rice straw, maize stover etc., are generally used as substitutive fodder as well as its supplement. These residues can be converted into high quality feed by means of fungal delignification, which

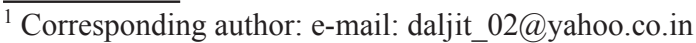


improves its nutritive value (Zadrazil and Brunnert, 1980; Reid, 1989; Vills-Boas et al., 2002). Natural degradation of plant residue is mainly caused by different fungal and bacterial species. Holocellulose and lignin are the biopolymers that are converted into low molecular weight compounds by the enzymatic action of these microorganisms. Fungi are usually better degraders of plant cell wall constituents because of their hyphal penetration power. Many fungal species have been screened for their potential to degrade cereal residues. White rot fungi are the most studied and degrade lignin efficiently by using their ligninolytic enzyme system (Agosin et al., 1985; Arora et al., 2002). Lignin is bound to cellulose and hemicellulose and makes these components inaccessible for microbial attack. Animal enzymatic system does not support ligninolysis and so these crop-residues are not completely digestible and thus of poor nutritive value. Fungal ligninolysis and break down of cellulose-hemicellulose matrix liberate simple degradable components that can be easily utilized by rumen microflora, thus improving the ruminant digestibility.

Phanerocheate chrysosporium is a well-known white rot fungus and most widely studied for lignin degradation. However, loss of total organic matter is very high during the degradation of lignocellulosics, which limits its practical use and necessitates looking towards selective ligninolytic organisms (Jung et al., 1992). Phlebia species are known selective lignin degraders (Arora and Gill, 2000) and thus may possess the potential capability for improvement of digestibility of agro-residues. Four white rot fungi including three different species of Phlebia and another widely studied fungus Ceriporiopsis subvermispora (Akin et al., 1995) were selected to find out their comparative role in selective ligninolysis and in vitro digestibility of wheat straw. In vitro digestibility was measured by using buffalo faecal matter rather than ruminant fluid as a substitutive source of microflora. This is relatively easy method than Tilley and Terry's (1963) two-stage in vitro procedure, which requires special surgical skills, fistulated animal, where special care is needed to keep fistula free from any infection. On the other hand, the method involving the use of enzymes, like cellulase, is relatively expensive (Nousiainen et al., 2003). Use of faecal inoculum for determining the digestibility is comparatively cheaper and easier method for practical use in a microbiological laboratory (Shaer et al., 1987; Akhter et al., 1999).

\section{MATERIAL AND METHODS}

\section{Organisms}

Four white rot fungi Phlebia radiata (MJL-1198), Phlebia brevispora (HHB7030), Phlebia fascicularia (FP-70880) and Ceriporiopsis subvermispora were 
used in the present study. All Phlebia spp. were received from T.W. Jeffries (Forest Product Laboratories, Madison, USA). The cultures were maintained by regular subculturing on yeast extract glucose agar (YGA) slants and stored at $4^{\circ} \mathrm{C}$ as well as at $-80^{\circ} \mathrm{C}$ in $10 \%(\mathrm{v} / \mathrm{v})$ glycerol.

\section{Experimental procedure}

Wheat straw (WS) used as a substrate was milled (particle size $2 \mathrm{~mm} \pm 0.5$ ), washed (with water at $25-30^{\circ} \mathrm{C}$ ) and dried at $90^{\circ} \mathrm{C}$. Five $\mathrm{g}$ of dried WS taken in $250 \mathrm{ml}$ conical flasks was moistened with $25 \mathrm{ml}$ of $0.5 \%(\mathrm{w} / \mathrm{v})$ malt extract and after sterilization at $1.06 \mathrm{~kg} / \mathrm{cm}^{2}$ for $15 \mathrm{~min}$, the flasks were inoculated with three mycelial discs $(8 \mathrm{~mm})$ per flask, grown on YGA plates for 6 days. All the flasks were incubated at $25^{\circ} \mathrm{C}$. Two flasks for each organism were processed at 10,20, and 30 days along with 2 uninoculated control flasks. The whole experiment was repeated three times. Thus, the data presented in Tables 1 and 2 is an average of six individual flasks. Enzyme extraction was done as described earlier (Arora et al., 2002). Twenty five $\mathrm{ml}$ of sodium acetate buffer $(10 \mathrm{mM}$, $\mathrm{pH}$ 5) was added to each flask and put on a rotary shaker at $200 \mathrm{rpm}$ for $20 \mathrm{~min}$. The contents of each flask were filtered on a tared filter paper and dried at $90^{\circ} \mathrm{C}$ until constant weight. Filtrate obtained was centrifuged at $8000 \mathrm{~g}$ at $4^{\circ} \mathrm{C}$ for 15 min and the extract thus obtained was used for laccase assay. The dried residue was used for different analytical tests.

\section{Analytical methods}

The sequential fractionation of lignocellulosics was carried out according to Datta (1981) with slight modifications. One g of WS was suspended in 100 $\mathrm{ml}$ distilled water, kept at $100^{\circ} \mathrm{C}$ for $2 \mathrm{~h}$ in a water bath and filtered on a tare crucible, residue was dried at $90^{\circ} \mathrm{C}$ till constant weight. Loss was considered as water soluble part. Dried residue was suspended in $100 \mathrm{ml}$ of $0.5 \mathrm{M} \mathrm{H}_{2} \mathrm{SO}_{4}$ and after keeping for $2 \mathrm{~h}$ at $100^{\circ} \mathrm{C}$ in a water bath, the contents were filtered, dried and weighed as described in the first step and loss in weight is represented as hemicellulose content. For cellulose and lignin estimations, $10 \mathrm{ml}$ of $72 \%(\mathrm{v} / \mathrm{v})$ $\mathrm{H}_{2} \mathrm{SO}_{4}$ was added to the above dried residue and kept at $30^{\circ} \mathrm{C}$ for $1 \mathrm{~h}$ on a rotary shaker at $200 \mathrm{rpm}$. After incubation the mixture was diluted up to $4 \%(\mathrm{v} / \mathrm{v})$ of $\mathrm{H}_{2} \mathrm{SO}_{4}$ and autoclaved at $1.06 \mathrm{~kg} / \mathrm{cm}^{2}$ for $40 \mathrm{~min}$. The contents were filtered, dried and weighed. The loss in weight was treated as cellulose, and the left over residue was considered as lignin.

For estimating the residual ash content, $1 \mathrm{~g}$ of sample was kept at $550^{\circ} \mathrm{C}$ for $5 \mathrm{~h}$ in a tare crucible and reweighed to calculate the residual ash content. Change in $\mathrm{pH}$ of the decomposed and undecomposed WS was determined by taking 
$500 \mathrm{mg}$ of WS in $10 \mathrm{ml}$ of distilled water and kept on a rotary shaker at $200 \mathrm{rpm}$ for $30 \mathrm{~min}$. $\mathrm{pH}$ was read with the help of $\mathrm{pH}$ meter.

\section{Laccase assay}

Laccase (EC 1.10.3.2) activity was measured as described earlier (Arora and Gill, 2005). Five $\mathrm{ml}$ of reaction mixture containing $10 \mathrm{mM}$ sodium acetate buffer (pH 5), $2 \mathrm{mM}$ guaiacol and $0.2 \mathrm{ml}$ of culture supernatant was incubated at $25^{\circ} \mathrm{C}$ for $2 \mathrm{~h}$ and the absorbance was read at $450 \mathrm{~nm}$. The relative enzyme activity has been expressed as colorimetric units $/ \mathrm{ml}(\mathrm{CU} / \mathrm{ml})$.

\section{Chitin estimation}

Chitin was measured according to Chen and Johnson (1983). All the fungi were grown in $50 \mathrm{ml}$ yeast extract glucose broth for 15 days at $25^{\circ} \mathrm{C}$. The fungal biomass so obtained was dried at $90^{\circ} \mathrm{C}$ for $24 \mathrm{~h}$. Ten $\mathrm{mg}$ of dried fungal biomass was refluxed at $100^{\circ} \mathrm{C}$ for $4 \mathrm{~h}$ in $5 \mathrm{ml}$ of $6 \mathrm{M}$ hydrochloric acid. After cooling to room temperature, hydrolysates were filtered and $1 \mathrm{ml}$ aliquots of such samples were withdrawn and evaporated to dryness at $60^{\circ} \mathrm{C}$ under reduced pressure. The dry hydrolysates were then redissolved in $4 \mathrm{ml}$ distilled water. To $1 \mathrm{ml}$ of this diluted solution, $0.25 \mathrm{ml}$ of acetylacetone ( $4 \%$ acetylacetone in $2.5 \mathrm{M}$ sodium carbonate) was added and heated at $90^{\circ} \mathrm{C}$ for $1 \mathrm{~h}$ in a capped test tube. After cooling, $2 \mathrm{ml}$ of ethanol and then $0.25 \mathrm{ml}$ of Ehrlich reagent (1.6 $\mathrm{g}$ of $\mathrm{N}$-N-dimethyl-p-aminobenzaldehyde in a $30: 30 \mathrm{ml}$ mixture of ethanol and concentrated HCI) was added. The colour formed was measured at $530 \mathrm{~nm}$. The glucosamine hydrochloride content of cell wall hydrolysates was determined by comparing its absorbance with that of standard glucosamine hydrochloride.

\section{In vitro digestibility}

In vitro digestibility of uninoculated and fungal treated WS was estimated according to Akhter et al. (1999), with slight modifications. Faecal inoculum was prepared by mixing fresh faecal matter of buffalo $(100 \mathrm{~g} / \mathrm{l})$ in pre-warmed $\left(39^{\circ} \mathrm{C}\right)$ artificial saliva $\left(\mathrm{NaHCO}_{3} 9.80 \mathrm{~g}, \mathrm{Na}_{2} \mathrm{HPO}_{4} .7 \mathrm{H}_{2} \mathrm{O} 7.00 \mathrm{~g}, \mathrm{KCl} 0.57 \mathrm{~g}\right.$, $\mathrm{NaCl} 0.47 \mathrm{~g}, \mathrm{MgSO}_{4} .7 \mathrm{H}_{2} \mathrm{O} 0.12 \mathrm{~g}$ and $1 \mathrm{ml} \mathrm{CaCl}(4 \%$, w/v) in $1000 \mathrm{ml}$ of distilled water) and filtered through four-layered muslin cloth. Five hundred $\mathrm{mg}$ WS (washed and dried) taken in $50 \mathrm{ml}$ centrifuge tube was suspended in $35 \mathrm{ml}$ of faecal inoculum. After flushing with $\mathrm{CO}_{2}$ gas, these tubes were kept at $39^{\circ} \mathrm{C}$ for $48 \mathrm{~h}$ in a water bath. Supernatant was discarded and $35 \mathrm{ml}$ of acidified pepsin ( $6.6 \mathrm{~g}$ in 11 of $0.1 \mathrm{M} \mathrm{HCl}$ ) was added to the residue. Tubes were again incubated at the same conditions for $48 \mathrm{~h}$. Residue was filtered on a tared filter paper and 
dried. The weight loss in dry matter during the incubation has been expressed as in vitro digestibility.

\section{Statistical analysis}

The data was represented as mean with standard deviation and analysed by two-way ANOVA (4 X 3 factorial design) and correlation.

\section{RESULTS}

Solid-state fermentation of wheat straw was carried out with different white rot fungi and compared with that of the properties of uninoculated WS. Uninoculated WS contains $85 \mathrm{~g} / \mathrm{kg}$ water solubles, $353 \mathrm{~g} / \mathrm{kg}$ hemicellulose, $325 \mathrm{~g} / \mathrm{kg}$ cellulose, $240 \mathrm{~g} / \mathrm{kg}$ lignin and $70 \mathrm{~g} / \mathrm{kg}$ residual ash with the in vitro digestibility of $143 \mathrm{~g} / \mathrm{kg}$ and $\mathrm{pH}$ 6.04. The fungi were examined for their potential to degrade different plant cell wall components and enhancement in in vitro digestibility during 30 days of incubation as stationary cultures at $25^{\circ} \mathrm{C}$ (Table 1 ).

All the fungi caused variable loss in total organic matter (TOM) during solid state fermentation of WS. P. radiata caused the maximum loss $(159 \mathrm{~g} / \mathrm{kg})$ during 30 days of incubation. P. fascicularia, $P$. brevispora and $C$. subvermispora did not show any statistically significant difference in the resultant loss in TOM, which ranged from 100-108 g/kg (Table 1). Different fungi were consistent in their rate of degradation during 30 days period except $P$. fascicularia, which caused more loss during 10-20 days of incubation.

A maximum of $127 \mathrm{~g} / \mathrm{kg}$ water soluble components were liberated by C. subvermispora during 20 days while $P$. brevispora and $P$. fascicularia liberated maximum water solubles during 30 days (120 and $98 \mathrm{~g} / \mathrm{kg}$, respectively) and $P$. radiata $(97 \mathrm{~g} / \mathrm{kg})$ during 10 days. C. subvermispora was more effective in the early period of incubation and released more water solubles during first 20 days with very little increase during further incubation while Phlebia species were more active in releasing water solubles in 20-30 days period (Table 1).

Hemicellulose was best degraded $(200 \mathrm{~g} / \mathrm{kg})$ by $C$. subvermispora during 30 days of incubation and followed by P. fascicularia $(189 \mathrm{~g} / \mathrm{kg})$, P. radiata $(150 \mathrm{~g} / \mathrm{kg})$ and $P$. brevispora $(118 \mathrm{~g} / \mathrm{kg}$ ) (Table 1). P. fascicularia degraded hemicellulose more efficiently during 20-30 days, while all other fungi degraded maximum amount of hemicellulose during initial stages of degradation, i.e. first 10 days of incubation.

$P$. fascicularia was the best degrader of cellulose and caused a maximum loss of $263 \mathrm{~g} / \mathrm{kg}$, followed by P. brevispora and C. subvermispora by causing around $190 \mathrm{~g} / \mathrm{kg}$ loss, whereas $P$. radiata caused a loss of $173 \mathrm{~g} / \mathrm{kg}$ in 30 days. $P$. radiata, $P$. brevispora and $C$. subvermispora were more active during 10-20 


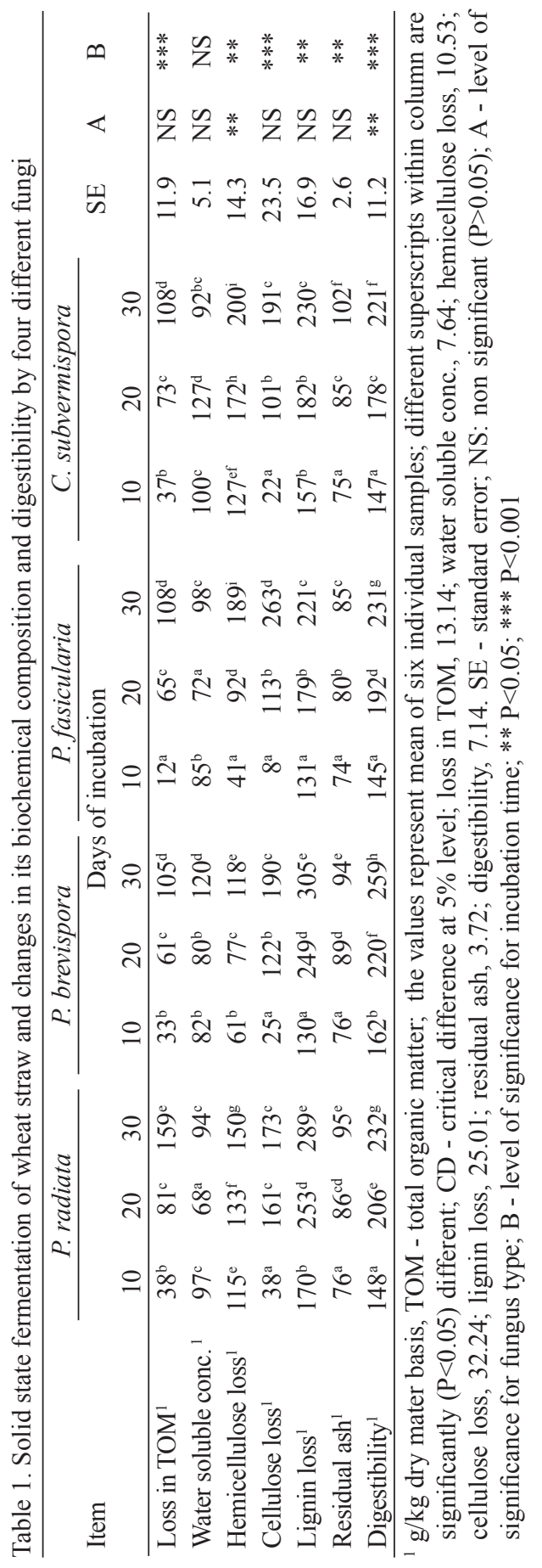


days in cellulose degradation as compared to P. fascicularia, which degraded cellulose more in last 10 days.

All the fungi were able to degrade lignin; P. brevispora was the best lignin degrader and resulted in maximum lignin loss of $305 \mathrm{~g} / \mathrm{kg}$ in 30 days of incubation. It was closely followed by $P$. radiata $(289 \mathrm{~g} / \mathrm{kg})$, whereas C. subvermispora and P. fascicularia caused a lignin loss of 230 and $221 \mathrm{~g} / \mathrm{kg}$, respectively. $P$. radiata and $C$. subvermispora were relatively faster degraders of lignin and resulted in 170 and $157 \mathrm{~g} / \mathrm{kg}$ loss in first 10 days of incubation, while $P$. brevispora was better in later stage of incubation, i.e. 20-30 days (Table 1).

In all the fungal treated substrates, $\mathrm{pH}$ declined sharply during first 10 days of incubation and fell to 3.5-5.4 as compared to uninoculated WS (pH 6.04). However, it increased slightly thereafter (Table 2). Residual ash content of

Table 2. Changes in $\mathrm{pH}$ profile of WS during its degradation by different fungi

\begin{tabular}{lcccc}
\hline \multirow{2}{*}{ Organisms } & \multicolumn{4}{c}{ Days of incubation } \\
\cline { 2 - 5 } & 0 & 10 & 20 & 30 \\
\hline P. radiata & 6.04 & 3.56 & 4.85 & 4.94 \\
P. fascicularia & 6.04 & 5.42 & 5.53 & 5.79 \\
P. brevispora & 6.04 & 3.81 & 4.96 & 4.98 \\
C. subvermispora & 6.04 & 3.59 & 4.52 & 4.94 \\
\hline
\end{tabular}

degraded WS increased with increase in incubation period and maximum resultant ash (in 30 days) was obtained from WS degraded by C. subvermispora (102 g/ $\mathrm{kg})$, which was followed by P. radiata $(95 \mathrm{~g} / \mathrm{kg})$, P. brevispora $(94 \mathrm{~g} / \mathrm{kg})$ and $P$. fascicularia $(85 \mathrm{~g} / \mathrm{kg})$. The residual ash content resulting from the degradation of WS by different fungi was statistically significant $(\mathrm{P}<0.05)$ except $P$. radiata and P. brevispora.

WS treated with $P$. brevispora showed the highest in vitro digestibility of $259 \mathrm{~g} / \mathrm{kg}$ followed by P. radiata $(232 \mathrm{~g} / \mathrm{kg})$, . P. fascicularia $(231 \mathrm{~g} / \mathrm{kg})$ and C. subvermispora $(221 \mathrm{~g} / \mathrm{kg})$ during 30 days, whereas the control WS showed $143 \mathrm{~g} / \mathrm{kg}$ digestibility. Difference in in vitro digestibility resulting from the WS treated with different fungi was statistically significant $(\mathrm{P}<0.05)$ except $P$. radiata and $P$. fascicularia. After first 10 days, only $P$. brevispora was able to enhance the digestibility up to a significant level which continued during the entire incubation period while other fungi enhanced digestibility during 10-30 days of incubation.

Different fungi showed different laccase production profile. P. brevispora was the best laccase producer and resulted in a maximum laccase production during 20 days, which was followed by $P$. fascicularia during 30 days, C. subvermispora during 10 days while laccase production by $P$. radiata was minimum as compared to other fungi (Figure 1). 

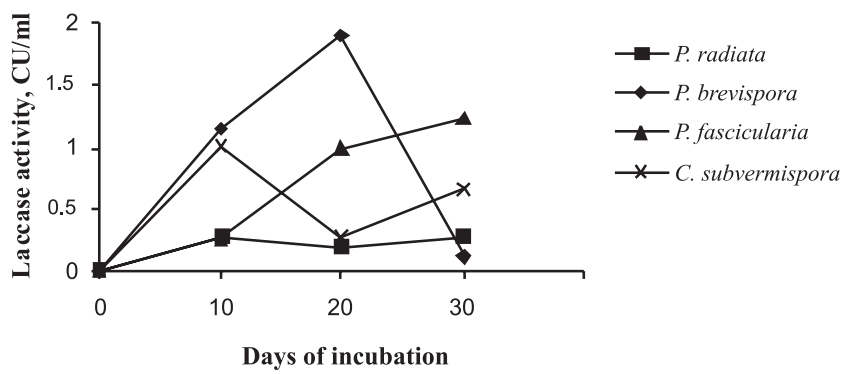

Figure 1. Laccase production by different white rot fungi during solid state fermentation of wheat straw for 30 days

C. subvermispora was the richest in chitin content $(320 \mathrm{~g} / \mathrm{kg})$, which was followed by $P$. fascicularia $(305 \mathrm{~g} / \mathrm{kg})$, . . radiata $(247 \mathrm{~g} / \mathrm{kg})$ and $P$. brevispora $(220 \mathrm{~g} / \mathrm{kg})$.

\section{DISCUSSION}

Chemistry of lignin confers resistance to wood and other agricultural residues against microbial attack. However, white rot fungi have got the necessary potential to degrade lignin because of their well defined ligninolytic enzyme system, which make them suitable candidates for delignification of forage crops to improve their digestibility (Zadrazil, 1977). Invariably these fungi also degrade cellulose and hemicellulose along with lignin. The loss of these components from the feed is not economically desirable because less biomass is available for animal feed. In an earlier study Phanerocheate chrysosporium, a common and widely studied fungus, degraded lignin but also caused a high loss in total organic matter (TOM) (Jung et al., 1992). To overcome this problem, selective ligninolysis needs to be carried out. In the present studies, all the white rot fungi promise to be a good choice of being selective lignin degraders with minimum loss in TOM.

From the experimental data, the lignin loss as caused by different fungi can be correlated with the enhancement of digestibility of substrate (Correlation coefficient $=0.915$, which shows a very strong positive correlation). In vitro digestibility of wheat straw was maximum in P. brevispora, which caused maximum lignin loss and minimum loss in TOM. All the fungi were selective in lignin degradation and enhanced the in vitro digestibility accordingly. It also supported the earlier observations of Mukherjee and Nandi (2004) during their study on two Pleurotus species. After 20 days of incubation $P$. brevispora enhanced the in vitro digestibility up to $220 \mathrm{~g} / \mathrm{kg}$ with $61 \mathrm{~g} / \mathrm{kg}$ loss in TOM and there was no statistically significant difference when compared with enhancement in the in vitro digestibility caused by 
C. subvermispora after 30 days of incubation with a simultaneous loss of $108 \mathrm{~g} / \mathrm{kg}$ in TOM (Table 1). Thus, the use of $P$. brevispora is practically beneficial for improving the quality of wheat straw. Next to $P$. brevispora, $P$. radiata and $P$. fascicularia gave almost similar results. $P$. radiata degraded more lignin than $P$. fascicularia but there was no statistically significant difference in the in vitro digestibility of substrate treated by these fungi. Both the Phlebia species had same impact on the digestibility improvement, but economically $P$. fascicularia may prove to be more suitable candidate because of minimum loss in TOM and faster rate of digestibility enhancement. Martínez et al. (2005) reported that lignin and hemicellulose were attacked initially while the cellulose degradation rate increased later, which is in consonance with the present study. Initially all the fungi consumed simple components which did not give any significant difference in digestibility except $P$. brevispora. Concentration of water soluble components depends upon the degradation of complex compounds like cellulose and hemicellulose, which are converted into lower molecular weight components. However, water solubles are not directly related to digestibility though may be significant nutritionally. $P$. radiata released maximum water solubles but it was unable to give a proportional enhancement of in vitro digestibility in consonance with earlier findings of Rolz et al. (1986) with lemon grass and citronella bagasse as substrate and 12 white rot fungi.

In line with maximum ligninolysis, $P$. brevispora gave the highest laccase yield followed by $P$. fascicularia and C. subvermispora. Though, laccase activity was minimum in $P$. radiata but it degraded the lignin in a very selective and efficient manner, which shows that the lignin degradation also depends upon other ligninolytic enzymes, i.e. mangnese peroxidase and lignin peroxidase, etc. (Arora et al., 2002).

Chitin is a basic structural component of fungal cell wall. Presence of fungal mycelia in these plant cells thus increase the chitin content, which may not be easily digested by ruminants. Amount of chitin depends upon the fungal species and its growing conditions. Thus, the chitin content may affect the digestibility of feed. Chitin may not be of much nutritional value to ruminants but its content can affect the digestibility of the fungal treated substrate. Maximum chitin was estimated in C. subvermispora, which showed the lowest increase in digestibility, while the fungus $P$. brevispora having the lowest chitin content enhanced the in vitro digestibility to its maximum extent, which is in the consonance with the study of Asiegbu et al. (1994). Other fungi also showed the relation between their chitin content and digestibility. P. floridensis also enhances the digestibility of WS up to $250 \mathrm{~g} / \mathrm{kg}$ with a minimum loss of TOM, this fungus also has a lower amount of chitin (data not shown). C. subvermispora and $P$. radiata also degraded lignin selectively making them suitable choice with specific reference to pulping industry (Yaghoubi et al., 2008) while P. brevispora may turn out to be better fungus for practical use to improve the digestibility of wheat straw. 


\section{REFERENCES}

Agosin E., Monties B., Odier E., 1985. Structural changes in wheat straw components during decay by lignin-degrading white rot fungi in relation to improvement of digestibility for ruminants. J. Sci. Food Agr. 36, 925-935

Akhter S., Owen E., Theodorou M.K., Butler E.A., Minson D.J., 1999. Bovine faeces as a source of micro-organisms for the in-vitro digestibility assay of forages. Grass Forage Sci. 54, 219- 226

Akin D.E., Rigsby L.L., Sethuraman A., Morrison W.H., Gamble G.R., Eriksson K.E.L., 1995. Alterations in structure, chemistry, and biodegradability of grass lignocellulose treated with the white rot fungi Ceriporiopsis subvermispora and Cyathus stercoreus. Appl. Environ. Microbiol. 61, 1591-1598

Arora D.S., Chander M., Gill P.K., 2002. Involvement of lignin peroxidase, manganese peroxidase and laccase in degradation and selective ligninolysis of wheat straw. Int. Biodeterior. Biodegrad. 50, $115-120$

Arora D.S., Gill P.K., 2000. Laccase production by some white rot fungi under different nutritional conditions. Bioresource Technol. 73, 283-285

Arora D.S., Gill P.K., 2005. Production of ligninolytic enzymes by Phlebia floridensis. World J. Microbiol. Biotechnol. 21, 1021-1028

Asiegbu F.O., Morrison I.M., Paterson A., Smith J.E., 1994. Analyses of fungal fermentation of lignocellulosic substrates using continuous culture rumen simulation. J. Gen. Appl. Microbiol. 40, 305-318

Chen G.C., Johnson B.R., 1983. Improved colorimetric determination of cell wall chitin in wood decay fungi. Appl. Environ. Microbiol. 46, 13-16

Datta R., 1981. Acidogenic fermentation of lignocellulose - acid yield and conversion of components. Biotechnol. Bioeng. 23, 2167-2170

Jung H.G., Valdez F.R., Abad A.R., Blanchette R.A., Hatfield R.D., 1992. Effect of white rot basidomycetes on chemical composition and in-vitro digestibility of oat straw and alfalfa stems. J. Anim. Sci. 70, $1928-1935$

Martínez Á.T., Speranza M., Dueñas F.J.R., et al., 2005. Biodegradation of lignocellulosics: microbial, chemical, and enzymatic aspects of the fungal attack of lignin. Int. Microbiol. 8, 195-204

Mukherjee R., Nandi B., 2004. Improvement of in-vitro digestibility through biological treatment of water hyacinth biomass by two Pleurotus species. Int. Biodeterior. Biodegrad. 53, 7-12

Nousiainen J., Rinne M., Hellämäki M., Huhtanen P., 2003. Prediction of the digestibility of the primary growth of grass silages harvested at different stages of maturity from chemical composition and pepsin-cellulase solubility. Anim. Feed Sci. Tech. 103, 97-111

Okano K., Iida Y., Samurai M., Prasetya B., Usagawa T., Watanabe T., 2006. Comparison of in-vitro digestibility and chemical composition among sugarcane bagasses treated by four white rot fungi. Anim. Sci. J. 77, 308-313

Reid I.D., 1989. Solid-state fermentation for biological delignification. Enzyme. Microb. Tech. 11, 786-803

Rolz C., Leon De R., Arriola De M.C., Cabrera De S., 1986. Biodelignification of lemon grass and citronella bagasse by white rot fungi. Appl. Environ. Microbiol. 52, 607-611

Shaer-El H.M., Omed H.M., Chamberlain A.G., Axford R.F.E., 1987. Use of faecal organisms from sheep for the in-vitro determination of digestibility. J. Agr. Sci. 109, 257-259

Tilley J.M.A., Terry R.A., 1963. A two-stage technique for the in-vitro digestibility of forage crops. J. Brit. Grassl. Soc. 18, 104-111 
Villas-Boas S.G., Esposito E., Mitchell D.A., 2002. Microbial conversion of lignocellulosic residues for production of animal feeds. Anim. Feed Sci. Tech. 98, 1-12

Yaghoubi K., Pazouki M., Shojaosadati A.S., 2008. Variable optimization for biopulping of agricultural residues by Ceriporiopsis subvermispora. Bioresource Technol. 99, 4321-4328

Zadrazil F., 1977. The conversion of straw into feed by basidiomycetes. Eur. J. Appl. Microbiol. 4, 273-281

Zadrazil F., Brunnert H., 1980. The influence of ammonium nitrate supplementation on degradation and in-vitro digestibility of straw colonized by higher fungi. Eur. J. Appl. Microbiol. Biotechnol. 9, 37-44 